\title{
YOU NEED TO STOP THIS, YOU NEED TO DISAPPEAR
}

She saw her each morning, the woman's figure framed in one of the windows across the street. Their apartments lined up, the same third floor of twin buildings, Calvert Gardens East and Calvert Gardens West. Carolyn would sit at the desk in her bedroom and wait for the woman to appear. It had become another notch in her morning routine, this act of watching the woman as much a part of Carolyn's early day as her first cup of coffee. At seven o'clock, the woman would open her blinds, admiring the world outside, exposing herself, naked from head to foot. She would stand at the window for thirty seconds, sometimes more. Then the woman would turn away, and Carolyn wouldn't see her again until the following morning, seven o'clock, always seven o'clock.

Carolyn had seen the woman every day for three weeks. For the first few days, she had sneaked only glances at her, each time expecting the woman to shut her blinds in a hurry, to gasp or cover herself and never appear in the window again. That simply never happened. Whether she was blind or just oblivious, the woman didn't seem to care that people might be staring at her. When Carolyn watched her, she felt like a ghost watching the hauntedthere and not there all at once.

She watched the woman now. It was overcast today, and the air was filled with a mist that drifted slowly north. The woman was slightly hazy, her figure obscured by the gauzy curtain between them. Still, Carolyn could see her well enough. She watched the woman's body, studied her hips, her breasts, her neck. She was rangy and tall, a few years older than Carolyn, late forties or early fifties. She wore her hair long, past her shoulders, auburn except for an area near the front, where her hair was suddenly streaked with a wide patch of white. She wasn't especially good-looking. Her breasts were heavy and drooping. Her nose was too bulbous. Her hips were too pointed and bony, like knuckles.

Yet in spite of these things, the woman was alluring. Carolyn had decided that was the best word for it, alluring. She had even looked it up in the dictionary-from Old French and, before that, from Latin, luere, a lure, originally a falconry term. 
Yes, there was something birdlike about the woman. It was hard for Carolyn to pinpoint how she felt, but when she looked at the woman, she filled up with a sense of awe and vague admiration, something like the feeling she used to get when she and Cameron and Michael still lived as one family way out in Howard County, where a red-tailed hawk sometimes perched in the tree outside their living room window. Wow. Can you believe that? Look at him. Just look at him. Carolyn knew she shouldn't have been watching the woman at all. But if the woman didn't want to be looked at, why would she stand there in the window like that? Carolyn couldn't help but look. She couldn't help but be-there was no other word for it-lured. She felt inexplicably invested in the woman, wondering each morning if she was happy, sad, hopeful, hopeless. Carolyn even talked to her sometimes, using the same brand of one-sided banter she'd used with the red-tailed hawk.

"How are things?" Carolyn said now, searching the woman's features. The woman's face was long. She didn't smile. At first this looked like an expression of indifference, but, after a moment, Carolyn could see only weariness. "I know," she said, nodding.

142 "Know what?"

Her son's voice made Carolyn jolt in her seat. She turned and quickly stood so that her back blocked the woman from Cameron. "Sorry," she said, shaking her head. "What's up?"

Cameron stepped inside the room. At fifteen, he was already taller than she was. He walked with long steps, arms swinging widely, head hunched. "You need to sign this," he said, holding out a folded sheet of bond paper, his first report card from ninth grade.

They had fought about it the night before. Cameron had received one $\mathrm{C}$, three Ds, and an F, a significant drop from the grades he had received the year before. The report card also noted that he'd been absent five times, despite the fact that he had never stayed home last quarter, not once. Cameron had given her the report card without saying a word, his eyes never looking straight at her, a surrender that struck Carolyn as remarkably innocent, something he would have done as a child.

That hadn't stopped her. Carolyn exploded, demanding to see his assignments, his tests, each and every marginal note his teachers had written him.

"And where do you go?" she'd asked at one point, shouting, standing close. "I just walk around," Cameron said.

"With who? With friends?" 
"No," Cameron replied. "I don't have any friends."

Even that hadn't stopped her. Carolyn worked herself into a rage, haranguing him for the better part of an hour. And for what? To scare him straight? To beat him into submission? To play the proper role of the authoritative parent - the responsible, commanding parent-the role that Michael had always refused? Or was it something else, some misguided way of saying, Cam, what's wrong? Tell me what's wrong. I don't know how to help you any more, not like I did when you were little. Carolyn could only guess.

She took the report card and sat on the edge of her desk, still blocking the window. Cameron studied an amber necklace he'd picked up from the top of Carolyn's dresser. She didn't worry about him seeing the woman, not now, not some other time. Hers was the only window that faced that side of the street, hers and the small window in the bathroom, which they always kept closed, blinds down. Carolyn wrote her initials beside the three Ds and the $\mathrm{F}$ and signed the bottom of the card, just as the instructions asked her to do. "Remember," she said, "I'm checking your homework now. Everything. Essays. Math. Biology. Your reading. Everything."

"Okay," Cameron said, still fiddling with the necklace. "Does this have any mosquitoes in it, like Jurassic Park?"

"No," Carolyn said. She handed the report card to Cameron, glancing up and down at him. He was still dressed in gym shorts and a Baltimore Orioles T-shirt, the clothing he wore to bed. "Hurry up," Carolyn said. "It's already seven o'clock."

Cameron crossed the room, setting the necklace on the dresser as he went. "I know exactly what time it is," he said, and he closed the door behind him.

Sometimes Carolyn thought that she saw the woman while commuting to work. Carolyn directed the seven-person art department of a Baltimore luxury living magazine, Baltimore Life and Lot. Their articles were short, but their photo spreads were expansive, pages and pages of magnificent living rooms, kitchens, dining rooms, family rooms, bathrooms, dens, and bedrooms. Carolyn never took the photos herself-she paid freelance photographers for that-but she did sift through thousands of pictures each month, picking and choosing at her discretion. She always included one photo of the family, the mother and father and the two young children, the boys wearing polo shirts and khakis, the girls wearing stylish Neiman's dresses so eerily identical to the clothing of an adult. 
Carolyn would be crawling through traffic, inching south toward her office, flashes of a hundred different homes skipping through her mind. Then she would glance beside her and see that familiar face behind the wheel of a nearby car.

She was next to the woman now. Carolyn had turned onto President Street, hit a block of traffic, and then, boom, there across the median was the woman, seated in an Acura suv. For a second, Carolyn was sure it was her. The shape of the face, the width of the shoulders, the expression on the lips and in the eyes-part calm, part pensive, part tired. No matter how many times Carolyn thought she saw the woman, no matter how many times she was wrong, each new sighting seemed real.

It wasn't that she was obsessed, or so she believed. It was just the same phenomenon she'd experienced after her divorce six years earlier. For months, she saw Michael everywhere, not because she missed him, but because he'd been such a constant in her life and suddenly was not. Her mind still saw him because her eyes always had. Carolyn was certain this explained it, but, from time to time, she doubted herself. When Michael drove from Annapolis to visit Cameron every other weekend, Carolyn sometimes asked if he'd been in the area earlier that week. Nope, he would say, friendly but stiff, that way they spoke to each other now, as though they were officemates or distant cousins. Not me, not this week. Would've called if I were in town. Would've seen Cam.

Traffic shifted forward. Carolyn's hands tightened around the wheel. It is the woman, she thought, and this time, as always, she really did believe it.

Then the illusion collapsed. No streak of white, not on that head of hair. Carolyn looked and looked again, making sure. Yes, she was wrong. That woman's hair was as evenly brown as the cap of an acorn. Traffic picked up. Somewhere in front of her, a car blared its horn. When the suv finally passed her, Carolyn had already started to think about which photos to include in the upcoming issue's table of contents.

She overslept the next morning, snapping awake at six fifty-five. For a minute, Carolyn sat in bed, shocked, incensed at her alarm. Then she remembered that she had gotten out of bed at the usual time, turned off the alarm, and retreated back to sleep. She remembered six o'clock the way a person might remember events from a night of heavy drinking-blurry and indistinct but undoubtedly real. That was how she remembered most of her senior year of 
college, days when she'd drunk too much, days before the era of responsibility, of children, of waking up on time. Carolyn rushed out of bed.

She ate a bowl of cereal while checking her e-mail at the kitchen table. The radio droned in the background. She checked the time. One minute past seven. The woman would be at her window now, watching the world, body bright with the bluish glow of the morning. Carolyn considered getting up, rushing to her room, but finally she decided not to. She enjoyed the act of waiting for the woman as much as she enjoyed actually seeing her. When Carolyn waited at her desk, the woman was a revelation. She appeared for her and only her. The woman came to Carolyn, not the other way around. If she rushed to her bedroom window now, seeing the woman would make her feel uncomfortable. In that moment, Carolyn would be intruding on the woman, violating her, at least indirectly. And Carolyn was no intruder. She was an observer. The difference was clear to her. She finished her cereal and closed her laptop.

The bathroom door was closed, which meant that it was unoccupied. When Cameron used the bathroom, he left the door half-open. Carolyn would often catch a glimpse of him seated on the toilet or, even worse, standing in front of the toilet, his back only partially turned. It was a habit that annoyed her, a habit Michael used to have as well. This brand of intimacy seemed so strange to her, so idly gross, a frankness that was very different than the nudity of the woman in the window. It didn't matter how many times Carolyn scolded her son; Cameron still forgot to close the door. Cam, she would snap. Sorry, he'd reply, and, with a lazy push, only then would he close the door.

Carolyn assumed that her son was in his room, getting dressed. Still, when she reached the bathroom door, she felt something in the air, a certain uneasiness, the way a beat of silence felt in the middle of an argument, silence that was thick and foreboding. Carolyn turned the knob-the doors were old-fashioned and had no locks. Then she knocked two quick times, making certain. Nothing. She pushed the door open.

Cameron was facing the window. When Carolyn opened the door, his body was bent at the waist, his ass jutting out as he leaned forward, moving as if he had just been punched in the stomach. Then he was fiddling with his pants and his belt, its big buckle clinking like the noise of loose change in a pocket. He didn't turn to look at her. He didn't gasp, didn't shout. His only focus was his clothes, his elbows jerking as his hands worked in front of him. Carolyn watched him, dazed. 
"Stop it," Cameron said finally, still not turning from the window. It was a strange thing for him to say, a command so weak and rushed, the words of a person being bullied. "Stop it."

"Sorry," Carolyn said, shaking her head, snapping out of her stupor. "I'm—" Her voice trailed off.

She stepped back, shutting the door as she went. The whole thing had lasted no more than a few seconds, but it seemed so much longer. In her room, she sat at her desk. All she could think of was work-which homes were slated for the upcoming issue, which neighborhoods, which people. Carolyn knew what was happening. Her mind was distracting itself, already scabbing over. A few minutes later, she opened her blinds, but the woman in the window was gone.

Carolyn busted her ass at the office, worked harder and more persistently than she had worked all month. The current issue was going to print the following day, and Carolyn was happy for the work, an excuse to will herself into thinking about something other than her son. Of course, she hadn't 146 really been surprised by the whole situation. He was a boy, a teenager, and that was what teenage boys did. That was what everyone did.

Yet each time this crossed her mind-be sensible, sensible, sensible-Carolyn felt disturbed. Unhinged. How often must she feel entirely out of her element with this boy? Normal or abnormal, typical or atypical, Cameron's episode in the bathroom didn't feel like something she could address head-on. It felt like, well, boy's stuff.

At its core, it wasn't that at all, and Carolyn knew it. Cameron was her child before he was her son, a human being before a gender or a sex. Still, she imagined that things would have been different had Michael been the one to catch Cameron doing that in the bathroom. Michael would have shrugged it off, even laughed it off. Ha! Boys will be boys! Give 'em any naked lady below the age of seventy and there's no stopping it!

Yes, that was exactly how Michael would have reacted, Michael in all his glibness, all his nah-things-are-fine-leave-it-alone indifference. No, you asshole, things weren't fine. Boys have a tendency of jerking off, sure, but somehow the episode in the bathroom seemed bigger than that, some kind of milestone in her and Cameron's relationship, though Carolyn couldn't quite put that milestone into words, not yet. But, admittedly, whatever it was, part of her wished for an ounce or two of Michael's indifference. Part 
of her wished for Michael's help, a revelation that only made Carolyn despise him more.

And that, in turn, helped solidify her resolve, a party line she had adopted so often in the past: address the situation-address everything-by not addressing it at all. That was what Carolyn had done before, and that was what she would do today. She made herself work. If she needed to, if creeping thoughts of Cameron or Michael or the lady in the window began to cloud her mind, Carolyn proofed and re-proofed the advertisements they had made for clients in-house, reading to herself out loud.

By the end of the day, she had burned out. She felt as though she were coming off a caffeine high; every fiber in her body felt brittle. That night, she and Cameron spoke very little, exchanging only a few words about their days. For dinner they ordered Chinese food and ate straight from the boxes, taking the cartons to their separate rooms and closing the doors behind them. Carolyn watched Law $\mathcal{E}$ Order and drifted into a nap, still holding her fork. An hour later, Cameron knocked on her door. "Homework," he said. That was it. She listened to him walk away. Carolyn got out of bed and met him in the kitchen.

They reviewed his work for half an hour. Carolyn asked him to summarize the novel he was reading for English-Steinbeck's Tortilla Flat, a book she had never read. Then she checked his math homework, or, at least, she checked to make sure that he had completed it.

That was the most she could do. Carolyn had long ago forgotten even the basic rules of algebra, all that stuff about the proper way to calculate an equation, whether you should start with the numbers in parentheses or the numbers to the power of so-and-so. She wanted to help her son if help was what he needed, but Carolyn couldn't help him even if he asked. She felt like a fraud, but, then again, this was how she had felt so many times before. Sometimes motherhood felt like a trick she was playing, as if at any moment, Cameron would snap to attention and tell her, Wait. You don't know what you're doing at all, do you?

"Good?" Cameron said. Carolyn was reading the last side of a four-page math worksheet. "Everything cool?"

"Sure," Carolyn said, and she turned the packet over. She slid it across the table to her son. "Anything else? What about philosophy?" The class was Cameron's elective course, the only grade that wasn't a D or an F on his last report card. 
Cameron opened a small blue binder and retrieved a sheet of paper from its front pocket. "It's just this free-response thing," he said. "We got a question from a philosophy website called philosphersnet.com, and now we have to answer it and explain our opinion. It's short. I'm going to do it when we get up."

"What's the question?"

Cameron raised the sheet of paper and began to read quickly, as if annoyed. "An old woman was very ill. On her deathbed she asked her granddaughter to promise that she would visit her grave once a week. The granddaughter didn't want to disappoint her, so she promised that she would. After her grandmother died, the granddaughter didn't keep her promise. She was too busy. She didn't tell anyone about her promise, and she never felt guilty for failing to do as she said she would. How do you judge the failure of the granddaughter to visit her grandmother's grave? Is it wrong, a little bit wrong, or not wrong at all?" Cameron looked up.

"What are you going to answer?" Carolyn said.

"Not wrong at all."

"And why do you think that?"

Cameron frowned. He slouched lower in his seat, stuffing his hands into the center pocket of his Georgetown sweatshirt. Carolyn had met Michael while he was attending law school there. At the time, she had been a graduate student in journalism at George Washington University. George the Lesser, Michael had called it, trying to pass this off as a joke. It had always bothered her, but even when Carolyn told him that she didn't like it, Michael never took her seriously. Her indignation made him smile all the more, the obnoxious grin of a person who didn't know he was being mean or perhaps simply didn't care to admit it. Sometimes Cameron smiled that way.

"It's not wrong," he said, "because the grandmother's dead. She doesn't know any better. It doesn't make any difference."

"It makes a difference to the granddaughter," Carolyn said. "She knows better."

Cameron looked down at the sheet of paper. "No," he said. "The granddaughter doesn't feel guilty. It says right here. It doesn't make a difference to either of them, one way or another."

"Okay," Carolyn said, and she straightened in her seat, "but shouldn't the granddaughter know better?" She thought for a second. "I mean, you said this exercise is about morality. Well, what's morality?" 
It had started raining since they first sat down. Fat drops of water now dotted the window above the sink. There was a hole in its screen, and sometimes, after a hard rain, Carolyn would open the window and find the soaked bodies of a dozen dead beetles, slick little lumps in the space between the screen and the window itself. She would always wonder why they were there. Maybe they came to the window in exhaustion, already dying from the downpour, or maybe they came because they thought it was safe, a place to wait the rain out. Either way, they died. With the tip of her finger, Carolyn would push the dead beetles away, through the hole, one by one, letting them fall to the sidewalk below. Cameron was looking at the window now. He turned back to her.

"Morality means something different for everybody," he said. "That's the whole point of the exercise. That's what Mr. Schneider told us."

"All right," Carolyn said, "so what's morality to you?"

"It's doing what's right."

"And a granddaughter not visiting her grandmother's grave is right?"

"Well," Cameron said, and he waited for a moment, "yeah. It's definitely not wrong. The granddaughter had better things to do, so she did them. And it didn't make a difference to the grandmother because she was dead. So, yeah, it was right. It was right for the granddaughter to not visit the grave and do something more important instead."

Carolyn didn't like the way this was going. She wasn't sure why she was arguing, but something egged her on, a nagging desire to disagree with whatever Cameron said. "But what do you define as important?" Carolyn continued. "How can the granddaughter gauge the importance of visiting her grandmother's grave versus doing something else?"

"She does what's important to her," Cameron said. "That's it."

"But what's important to the grandmother is visiting the grave. So isn't that important to the granddaughter as well?"

"No," Cameron said, raising his voice, frustrated, "it's not important to her. Obviously it's not important to her. And it's not important because the grandmother doesn't know. It's a victimless crime."

Something caught in his throat and he turned, covering his mouth with one fist and coughing off to the side. As Cameron pivoted, Carolyn thought of him in the bathroom earlier that morning, fidgeting, struggling, fighting to hide himself. Stop it, he had said. And, for several seconds, Carolyn hadn't stopped. She'd continued to stare, dazed, that image of him burning 
into the folds of her brain, gray tissue getting one more ripple. She looked at the window above the sink and imagined herself out there in the darkness, her figure framed within a bright square like the woman across the street. Just like her. Standing. Lit. Exposed. Then she thought of Cameron, doing that not to the woman in the window but to her. She imagined that he was watching her, that she was watching him. That was why it bothered her-not because of the act itself or the awkwardness of catching him. It bothered her because she felt, in some larger way, that Cameron had been doing that to her all along, not as his mother but as another human being, another naked body. Then all that Carolyn could think about was beetles, black beetles, and whether they were now gathering on the sill—drowning, flailing, dying. She turned her eyes back to Cameron, just as he finished his spate of coughing.

"Don't worry," he said, and he cleared his throat. He smiled. It was that smile. "I'll visit your grave when you die."

That night, Carolyn drifted through an uneasy haze between consciousness and dreaming. From time to time, she glanced at the clock beside her bed, 150 squinting at the bright red digits-two thirty, three fifteen, four o'clock. The morning moved ahead like that, skipping, twitching. Each time Carolyn closed her eyes, the only thing she saw was Cameron watching her, wide black space between them, one lit room facing another. Her dreams felt like waking and her waking felt like dreams. The night was all mixed up.

When Cameron's silhouette appeared in her doorway-dark and quietCarolyn couldn't tell if she was dreaming or awake, not at first. She stared back at him, her head raised slightly from the pillow. How long had he been standing there? She blinked a few times, shook her head, looked at the clock. Five forty-five.

"Mom," Cameron said, and he stepped inside her room.

Carolyn sat up, breathing faster now. "Cam," she said. "What is it?"

He walked to the foot of her bed. He wore shorts and a plain blue T-shirt. "Mom," he said. "I feel like shit."

Why, Carolyn almost replied, her mind still fuzzy. You feel bad because of the woman in the window? She rubbed her hand over her eyes. Cameron felt sick, physically sick. Cameron, her kid. "Oh," Carolyn said, and she moved to push the sheets off her legs.

Cameron said that he felt nauseous. His knees hurt. His shoulders hurt. His body shivered with light chills, and, unless the room was dark, the back 
of his head throbbed. His temperature was a little high, just below a hundred. For a steady hour, Carolyn took care of him-brought him ibuprofen, fixed a small sandwich for him to eat, sat by his bedside, listened to every complaint about his stomach and his head.

Even with a looming deadline at work, she planned to take the day off, just for him. No-for her as well. Carolyn couldn't deny it: something pleased her about this, satisfied some primeval desire to heal and protect someone else. And not just anybody. Her child. When Cameron was younger, Carolyn had slept beside him when he was sick, his little form curled up in her arms. She knew then and remembered now that the pleasure she felt from taking care of him wasn't entirely earnest. It wasn't just the satisfaction of healing her child. Beyond that was an even simpler pleasure, a deep-down contentment that came from controlling someone else, from holding someone who was weaker than herself. Carolyn knew this wasn't exactly healthy, but she also knew - she thought - that it wasn't abnormal. Now, today, in that single hour beside her son's bed, Carolyn felt a degree of serenity she hadn't felt in years. Cameron didn't often feel sick, and when he did, he didn't let her treat him like this. Pamper him. Care for him. Watch him and watch over him.

"Can you bring me some orange juice?" Cameron asked her, flipping from his stomach to his back.

Carolyn closed her eyes, thinking. She sat in a chair next to his nightstand, hands folded in her lap. "We don't have any orange juice."

"Can you get me some?"

Yes. She certainly could. In a way, nothing would please her more.

Carolyn dressed and went downstairs, headed for the BP two blocks away. Traffic was picking up. The sun had already risen. Soon it wouldn't rise until seven o'clock or later, autumn easing into winter, briskness into cold. Would the woman in the window keep her schedule? Would she wake at the same time each morning, regardless of the season or the sunrise? Probably. The woman was like Carolyn. That was clear enough. Punctual. Consistent. Yet Carolyn had to wonder how long this could continue, how many weeks could pass before the woman spotted her neighbor-neighbors-across the street. Can't you see me? I'm watching you. And my son, my son is watching you, too. Doesn't that bother you? It bothers me. Maybe one day, Carolyn would mouth a message to her. Close. Your. Blinds. Leave. Us. Alone. Or maybe she would simply write the woman an anonymous letter, drop it in her mailbox across the street. Please. My son can see you. You need to stop this. You need to disappear. Please. 
She bought a quart of orange juice and headed back to her building. But when Carolyn reached her front steps, she turned and stared across the street. The woman's mailbox. In all this time, Carolyn had never thought of it. And why should she have? She'd had no need for it, no desire to fit any word to that body in the window. Now she couldn't resist. She felt herself being drawn across the street. Lured.

The apartment numbers for Calvert Gardens East were the same as for Calvert Gardens West, only preceded by "E" instead of "W." The woman's apartment number was sixty-three, the same as the person who lived across the hallway from Carolyn. She found the box quickly enough, there in its spot in the second row. But it had no name, only a fat white label that read RESIDENT.

"Fair enough," Carolyn said, and she smiled, leaning away from the box. "You like your privacy."

She turned to cross the street and return to her building. Yet glancing up, she saw her son sitting at her desk, the desk in her bedroom, three stories up. Streaks of glare shimmered across the glass. She couldn't see him very clearly—just the outline of his shoulders and his head—but even so, Carolyn was certain that it was Cameron in the window.

She didn't need to check the time. She knew it well enough. But was he really doing that, there? It could have been the case that Cameron was only watching the woman. It could have been the case that this was all he had ever done, or, at least, all that he had done most of the time. And now that Carolyn thought of it, perhaps she was mistaken entirely. Perhaps she was looking at the wrong window. She tried to count them, to find her own apartment, ticking off the windows from the left, the right, top, bottom. Each time she lost track. The longer she looked, the more she noticed other people in other windows, blurry forms behind panes of glass. Everyone looked more or less the same, obscured by the sunlight that shined so brightly on her building, her half of the street, the brighter half. When Carolyn looked again at the window she thought was her own, Cameron was gone.

He was lying on his side when she walked into his room. His back was turned to her. His sheets were pulled high, all the way up to his neck. Carolyn stopped beside his bed. She held a full glass of juice in one hand.

"Here you go," she said.

Cameron was quiet for a moment. Then, “Thank you.” He didn't move. 
Carolyn set the glass on the nightstand. "It's here," she said. "Right here." She watched him, studied the slow rhythm of his breathing. "Do you need anything else?" she asked. "Anything at all?"

"No," Cameron said. "I don't think so."

The room was cool and dark. The blinds were shut tight. The world outside was little more than a square of faint light, a dim yellow outline of the morning. Carolyn almost turned to leave, but, before she really even knew it, she was lying beside Cameron, her arms around his body, cradling him. This was her son, her boy.

"Mom," Cameron said.

Carolyn held him tighter, pulling closer to his back even as she felt him tense, slipping away from her. "Yes?" she said, and her eyes began to burn with tears.

"Can you leave me alone?" 